\section{JPHK " HUKUM DAN KEADILAN}

Vol. 1 No. 2, September 2020

P-ISSN: 2746-0967, E-ISSN: 2721-656X
Gedung Pascasarjana Kampus Terpadu UMY Jalan Brawijaya, Tamantirto, Kasihan, Bantul, Yogyakarta 55183

Telepon : (0274) 387656 Ext. 346

Email : jphk@umy.ac.id

\title{
Diskresi Kepolisian Melalui Mediasi Penal (Studi Kasus di Polsek Galur, Kulonprogo)
}

Priyo Santoso

Magister Hukum, Universitas Muhammadiyah Yogyakarta

E-mail:priyosantoso152@gmail.com

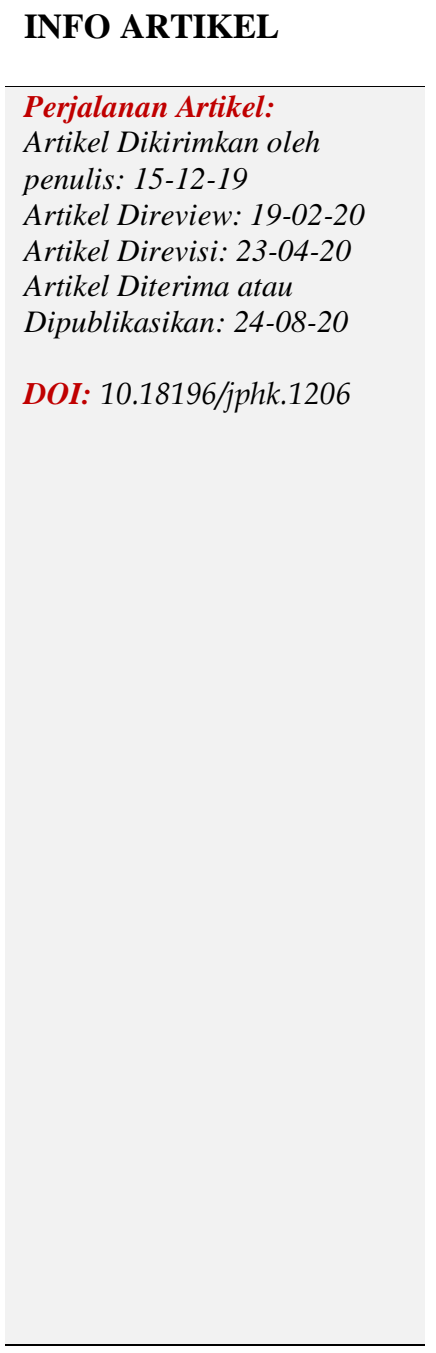

\begin{abstract}
ABSTRAK
Pelaksanaan mediasi penal oleh Kepolisian dapat dilaksanakan berdasarkan diskresi. Penelitian ini dilakukan untuk mendeskripsikan dan menganalisis pelaksanaan mediasi penal yang dilaksanakan berdasarkan diskresi oleh perpolisian masyarakat di Polsek Sektor Galur beserta faktor pendukung dan penghambat dari pelaksanaan mediasi penal oleh perpolisian masyarakat di Polsek Galur. Di akhir tulisan disampaikan rumusan pola ideal mediasi penal yang dilaksanakan berdasarkan diskresi oleh kepolisian masyarakat di masa mendatang. Metode penelitian hukum yuridisempiris (socio-legal research) menemukan fakta empiris bahwa pelaksanaan mediasi penal berdasarkan diskresi oleh Polsek Sektor Galur dilaksanakan melalui institusi perpolisian masyarakat dengan melibatkan banyak pihak, antara lain pihak pelaku dan korban, juga melibatkan stakeholder seperti tokoh masyarakat dan tokoh agama yang tergabung di FKPM. Faktor pendukung pelaksanaan mediasi pidana oleh Kepolisian Sektor Galur yaitu: dukungan undangundang Nomor 2 tahun 2002 tentang Kepolisian Negara Republik Indonesia yang memberikan kebebasan kepada pihak kepolisian pada saat pelaksanaan segala tugas, kewajiban dan wewenangnya dalam penegakan hukum; Kedua, petugas penyidik. Faktor penghambat yaitu: sarna dan prasarana; dukungan masyarakat; budaya yang tumbuh di masyarakat; keberadaan institusi kepolisian. Pola ideal diskresi yaitu dengan ketidakberpihakan mediator yang ditunjuk baik terhadap pelaku maupun korban.
\end{abstract}

Kata Kunci: Alternative Dispute Resolution, Mediasi Penal, Perpolisian Masyarakat

\section{Pendahuluan}

Mediasi penal merupakan salah satu metode dalam menyelesaikan perkara pidana yang dikehendaki oleh masyarakat yang terlibat perselisihan ataupun sengketa antar anggota masyarakat. Dalam mediasi penal, tidak terdapat salah satu pihak yang dikalahkan atau dimenangkan, sehingga diharapkan pasca penyelesaian perkara dengan model mediasi penal ini anggota masyarakat yang bersengketa dapat hidup rukun berdampingan kembali seperti sediakala. 
Mediasi Penal ${ }^{1}$ menurut Barda Nawawi Arief merupakan salah satu bentuk alternatif penyelesaian sengketa di luar pengadilan (Alternative Dispute Resolution atau Apropriate Dispute Resolution)2. Alternative Dispute Resolution (ADR) pada umumnya digunakan di lingkungan kasus-kasus perdata ${ }^{3}$, tidak untuk kasus-kasus pidana. Dalam perkembangan hukum di Indonesia, berdasarkan perundang-undangan yang berlaku pada, walaupun prinsipnya kasus pidana tidak dapat diselesaikan di luar pengadilan, akantetapi dalam hal-hal tertentu dimungkinkan adanya penyelesaian kasus pidana di luar pengadilan. Praktek penyelesaian perkara pidana di luar pengadilan selama ini tidak ada landasan hukum formalnya, sehingga sering terjadi suatu kasus yang secara informal telah ada penyelesaian damai (walaupun melalui mekanisme hukum adat), namun tetap saja diproses ke pengadilan sesuai hukum yang berlaku.

Istilah ADR menurut Muladi muncul karena adanya dialog antara yang berselisih untuk menyelesaikan masalahnya, merupakan langkah positif, dan dalam hal-hal tertentu lebih memenuhi tuntutan keadilan dan efesien. Model konsensus yang dianggap menimbulkan konflik baru harus diganti dengan model asensus, karena dialog dalam penyelesaian perselisihan adalah langkah yang sangat positif. Selanjutnya Muladi menyatakan bahwa ADR merupakan bagian dari konsep restorative justice yang menempatkan peradilan pada posisi mediator ${ }^{4}$. Proses dialog dipergunakan dalam penyelesaian di luar pengadilan sebenarnya telah dipergunakan oleh masyarakat Indonesia, yakni ketika salah satu orang anggota masyarakat adat melanggar atau melakukan tindak pidana adat, maka penyelesaian di luar pengadilan melalui mekanisme adat atas tindak pidana adat diselesaikan atau dimediasi oleh struktur adat seperti Raja, Kepala Desa, Tokoh Masyarakat, dengan mempertemukan dan mendamaikan para pihak yang terlibat perselisihan. Proses dialog dikedepankan dalam mediasi tersebut, para pihak didorong untuk mencari solusi yang menguntungkan, menghilangkan rasa denda, dan saling maaf-memaafkan ${ }^{5}$.

Dalam hukum positif Indonesia mediasi penal untuk penyelesaian perkara pidana secara eksplisit belum mendapatkan payung hukum, karena pada dasarnya

\footnotetext{
${ }^{1}$ Mediasi penal (penal mediation) disebut dengan berbagai istilah, seperti: "mediation in criminal cases" atau "mediation in penal matters" (Inggris), strafbemiddeling (Belanda), "Der Außergerichtliche Tataus-gleich" (Jerman), dan"de mediation pénale"(Perancis). Dalam mediasi penal dilakukan dengan mempertemukan pelaku tindak pidana dengan korban, maka mediasi penal disebut juga dengan istilah "Victim-Offender Medi-ation" (VOM), Täter-Opfer-Ausgleich (TOA), atau Offender-victim Arrangement (OVA).

2 Barda Nawawi Arief. (2008). Mediasi Penal: Penyelesaian Perkara Pidana Di Luar Pengadilan, Makalah Seminar Program Doktor Ilmu Hukum UNDIP, Jakarta, 27 Maret 2007.

${ }^{3}$ Lihat UU No. 30/1999 tentang Arbitrase dan Alternatif Penyelesaian Sengketa.

${ }^{4}$ Sahuri Lasmadi. (2011). Mediasi Penal, Sistem Peradilan Pidana Indonesia. Inovatif, Vol.4, No.5, Juli 2011, pp. 1-10.

${ }^{5}$ Rudini Hasyim Rado, Barda Nawawi Arief, Eko Soponyono. (2016). Kebijakan Mediasi Penal Terhadap Penyelesaian Konflik Sara Di Kepulauan Kei Dalam Upaya Pembaharuan Hukum Pidana Nasional. Jurnal Law Reform, Vol.12, No.2, Tahun 2016, pp. 266-276.
} 
regulasi Criminal Justice System (CJS) Indonesia tidak mengatur penyelesaian perkara di luar pengadilan. Hal tersebut berakibat pada beberapa kasus yang secara informal telah di selesaikan damai melalui mekanisme hukum adat, namun tetap saja di proses ke pengadilan sesuai dengan regulasi sistem peradilan pidana Indonesia.

Banyaknya perkara tindak pidana ringan yang masuk ke pengadilan juga telah membebani pengadilan, baik dari segi anggaran maupun dari segi persepsi publik terhadap pengadilan. Umumnya masyarakat tidak memahami bagaimana proses jalannya perkara pidana sampai bisa masuk ke pengadilan, pihak-pihak mana saja yang memiliki kewenangan dalam setiap tahapan, dan masyarakat pun umumnya hanya mengetahui ada tidaknya suatu perkara pidana hanya pada saat perkara tersebut disidangkan di pengadilan. Ketika sudah sampai pada tahap persidangan di pengadilan, sorotan masyarakat kemudian hanya tertuju pada pengadilan dan menuntut agar pengadilan mempertimbangkan rasa keadilan masyarakat. ${ }^{6}$

Over kriminalisasi juga menjadi problem penanggulangan tindak pidana di Indonesia. Lembaga pemasyarakatan semakin penuh oleh narapidana dengan berbagai ragam latar belakang kasus. Hal ini menjadikan lembaga pemasyarakatan sebagai tempat rehabilitasi semakin tidak manusiawi sebagai akibat dari buruknya fasilitas karena kelebihan kapasitas. Bahkan buruknya fasilitas lembaga pemasyarakatan tersebut seringkali menimbulkan konflik di antara sesama narapidana penghuni lembaga pemasyrakatan yang berujung pada kerusuhan.

Dalam perkembangan pembaharuan hukum pidana di berbagai negara, mediasi pidana/penal cenderung dipergunakan sebagai salah satu alternatif penyelesaian masalah di bidang hukum pidana ${ }^{7}$. Mediasi pidana yang dikembangkan berdasarkan pada empat prinsip kerja (working principles) ${ }^{8}$, yaitu: (a) Penanganan konflik (Conflict Handling/onfliktbearbeitung), bahwa kejahatan telah menimbulkan konflik interpersonal, sehingga konflik inilah yang dituju oleh proses mediasi, sehingga para pihak diarahkan untuk terlibat dalam proses komunikasi. (b) Berorientasi pada proses (Process Orientation; Prozessorientierung), Mediasi penal lebih berorientasi pada kualitas proses daripada hasil, yaitu: menyadarkan pelaku tindak pidana akan kesalahannya, kebutuhan-kebutuhan konflik terpecahkan, ketenangan korban dari rasa takut. (c) Proses informal (Informal Proceeding - Informalität), Mediasi penal merupakan suatu proses yang informal, tidak bersifat birokratis, menghindari

\footnotetext{
${ }^{6}$ Lihat dalam Penjelasan Peraturan Mahkamah Agung Republik Indonesia No. 2 Tahun 2012 tentang penyesuaian batasan Tindak Pidana Ringan dan Jumlah Denda dalam KUHP

7 Detlev Frehsee (Professor of Criminology and Criminal Law, University of Bielefeld, Germany), "Restitution and Offender-Victim Arrangement in German Criminal Law: Development and Theoretical Implications", http:// wings.buffalo.edu/law/ bclc/bclr.htm.

${ }^{8}$ Stefanie Tränkle, The Tension between Judicial Control and Autonomy in Victim-Offender Media-tion - a Microsociological Study of a Paradoxical Procedure Based on Examples of the Mediation Process in Germany and France, http://www. iuscrim.mpg.de/forsch/krim/traenkle_e.html. sebagaimana dikutip oleh Barda Nawawi Arief
} 
prosedur hukum yang ketat. (d) Ada partisipasi aktif dan otonom para pihak (Active and Autonomous Participation - Parteiautonomie/Subjektivie-rung).

Barda Nawawi Arief, latar belakang pemikiran untuk mengupayakan adanya mediasi penal, dikaitkan dengan ide-ide pembaharuan hukum pidana, antara lain: ide perlindungan korban, ide harmonisasi, ide restorative justice, ide mengatasi kekakuan/formalitas dalam sistem yang berlaku, ide menghindari efek negatif dari sistem peradilan pidana dan sistem pemidanaan yang ada saat ini, khususnya dalam mencari alternatif lain dari pidana penjara (alternative to imprisonment/alter-native to custody $)^{9}$. Di samping juga dikaitkan dengan masalah pragmatisme, antara lain untuk mengurangi stagnasi atau penumpukan perkara ("the problems of court casé overload"), untuk penyederhanaan proses peradilan ${ }^{10}$.

Dalam sistem peradilan pidana Indonesia, tidak dapat dilepaskan dari peran kepolisian. Kepolisian dalam menegakkan hukum pidana memiliki kewenangan diskresi sebagaimana disebutkan dalam Pasal 18 Undang-undang Nomor 2 Tahun 2002 tentang Kepolisian Republik Indonesia (selanjutnya disebut UU Polri) yang menyebutkan bahwa “(1) Untuk kepentingan umum pejabat Kepolisian Negara Republik Indonesia dalam melaksanakan tugas dan wewenangnya dapat bertindak menurut penilaiannya sendiri; (2) Pelaksanaan ketentuan sebagaimana dimaksud dalam ayat (1) hanya dapat dilakukan dalam keadaan yang sangat perlu dengan memperhatikan peraturan perundang-undangan, serta Kode Etik Profesi Kepolisian Negara Republik Indonesia".

Polri selaku pengayom, peranan Kepolisian Negara Republik Indonesia perlu dikembangkan melalui pemantapan kewenangan bertindak menurut penilaian sendiri untuk kepentingan umum, sehingga upaya perlindungan dan pelayanan terhadap masyarakat dapat dilaksanakan sebaik-baiknya (penjelasan Pasal 18 Undang-undang Nomor 2 Tahun 2002 tentang Kepolisian Republik Indonesia). Sehubungan dengan itu, maka praktek kepolisian selama ini yang tidak melakukan penyidikan perkara yang serba ringan sifatnya demi kepentingan umum dapat dipandang sebagai upaya pengayoman, sehingga dapat terus berlangsung. Termasuk pula dalam hal ini peranan pembina fungsi kepolisian yang tumbuh dan berkembang secara sosiologis dalam tata kehidupan masyarakat.

Berdasarkan uraian di atas, terlihat bahwa meskipun mediasi penal secara eksplisit belum diatur di dalam peraturan perundang-undangan, namun ketentuan dalam peraturan perundangan sebagaimana disebutkan di atas secara implisit memperlihatkan bahwa penyelesaian perkara tindak pidana di luar proses pengadilan telah diafirmasi dalam undang-undang. Ketentuan diskresi kepolisian sebagaimana disebutkan dalam UU Polri di atas telah memberi kewenangan kepada kepolisian dalam proses penyelesaian perkara pidana di luar pengadilan (discretion). Selain itu, kewenangan yang diberikan kepada Kepolisian Negara Republik Indonesia sebagai

\footnotetext{
${ }_{9}$ Sahuri Lasmadi, op. cit.

${ }^{10}$ Ibid.
} 
institusi pengak hukum yang bertanggungjawab untuk menjaga keamanan dan ketertiban secara tersirat dapat dijadikan pijakan dalam menyelesaikan perkara pidana di luar pengadilan.

Terkait dengan prosedur mediasi penal oleh kepolisian, secara parsial dan terbatas dapat dilihat dalam Surat Kapolri No Pol: B/3022/XII/2009/SDEOPS tanggal 14 Desember 2009 tentang Penanganan Kasus Melalui Alternatif Dispute Resolution (ADR) dengan langkah-langkah penanganan sebagai berikut: 1) Mengupayakan penanganan kasus pidana yang mempunyai kerugian materi kecil, penyelesaiannya dapat diarahkan melalui konsep ADR; 2) Penyelesaian kasus pidana dengan menggunakan ADR harus disepakati oleh pihak-pihak yang berperkara namun apabila tidak terdapat kesepakatan baru diselesaikan sesuai dengan prosedur hukum yang berlaku secara profesional dan proporsional; 3) Penyelesaian kasus pidana yang menggunakan ADR harus berprinsip pada musyawarah mufakat dan harus diketahui oleh masyarakat sekitar dengan menyertakan RT/RW setempat; 4) Penyelesaian kasus pidana dengan menggunakan ADR harus menghormati norma sosial/adat serta memenuhi azas keadilan; 5) Memberdayakan anggota Polmas dan memerankan FKPM yang ada di wilayah masing-masing untuk mampu mengindentifikasi kasus-kasus pidana yang mempunyai kerugian materiil kecil dan memungkinkan untuk diselesaikan melalui konsep ADR; dan 6) Untuk kasus yang telah dapat diselesaikan melalui konsep ADR agar tidak lagi disentuh oleh tindakan hukum lain yang kontra produktif dengan tujuan Polmas.

Polri saat ini harus menjadi sebuah lembaga negara yang benar-benar menjadi representasi masyarakat dan memiliki pola tindakan dan fungsi sebagai control sosial, paradigma kemitraan, partisipatif, professional, kesadaran (tidak dengan mengedepankan cara pemaksaan) dan komunitas (tidak individualis). Hal itu hanya dapat dilakukan jika Polri serius mengimplementasikan strategi yang telah ditetapkan dalam Surat Keputusan Kapolri No. Pol: SKEP/737/X/2005 tentang Kebijakan dan Strategi Penerapan Polmas. Model perpolisian masyarakat yang telah diadopsi oleh Polri pada tanggal 13 Oktober 2005 tersebut, diyakini sebagai strategi baru perpolisian di Indonesia untuk menekan angka kejahatan di tengah-tengah masyarakat.

Selain membawa berbagai manfaat, pola penyelenggaraan tugas Polri dengan membentuk Polmas sebagai garda terdepan dalam menekan angka kejahatan, melalui pendekatan "Bimmas/Babinkamtibmas" yang mencerminkan hubungan struktural "Kekuasaan" dipandang perlu untuk disesuaikan dengan perkembangan masyarakat madani. Mengingat program ini merupakan sesuatu yang baru dalam jajaran kepolisian (perubahan paradigma konvensional dalam tubuh Polri), maka sangat dimungkinkan jika pelaksanaannya masih belum bisa berjalan optimal dan belum efektif. Berbagai kendala sangat dimungkinkan muncul dalam mengimplementasikan program tersebut. Termasuk dalam hal ini adalah apa yang dilakukan oleh Kepolisian Sekor Galur, Polres Kulonprogo. 
Dalam rangka melaksanakan Surat Keputusan Kapolri No. Pol: Skep/737/X/2005 tentang Polmas di Kabupaten Kulonprogo, di tiap Kecamatan dibentuk perpolisian masyarakat. Dalam praktiknya, mediasi penal yang dilakukan oleh kepolisian Sektor Galur sejalan dengan ketentuan UU Polri dan Surat Keputusan Kapolri di atas telah berjalan sejak lama dipergunakan untuk menyelesaikan konflik yang terjadi di masyarakat.

Berdasarkan uraian latar belakang di atas, maka rumusan masalah dalam penelitian ini adalah:

I. Bagaimana pelaksanaan mediasi penal yang dilaksanakan berdasarkan diskresi oleh perpolisian masyarakat di Polres Kulonprogo Sektor Galur?

2. Apa saja faktor pendukung dan penghambat dari pelaksanaan mediasi penal oleh perpolisian masyarakat di Polres Kulonprogo Sektor Galur?

3. Bagaimana pola ideal mediasi penal yang dilaksanakan berdasarkan diskresi oleh kepolisian masyarakat di masa mendatang?

\section{Metodologi}

\subsection{Jenis Penelitian}

Jenis penelitian yang dilakukan penulis termasuk ke dalam jenis penelitian hukum yuridis-empiris (socio-legal research). Penelitian hukum yuridis dilakukan dengan cara meneliti bahan pustaka yang merupakan data sekunder dan penelitian ini disebut juga penelitian hukum kepustakaan. ${ }^{11}$ Sedangkan penelitian hukum empiris adalah penelitian yang menggunakan sumber data yang diperoleh langsung dari aktifitas masyarakat dengan melalui penelitian lapangan.Penelitian ini menggunakan dua pendekatan hukum normatif. Pendekatan hukum yuridis dilakukan dengan cara mengidentifikasikan dan mengkonsepkan hukum sebagai norma, kaidah, peraturan, Undang-undang yang berlaku pada suatu waktu dan tempat tertentu sebagai produk dari suatu kekuasaan negara tertentu yang berdaulat yang kemudian sering pula disebut sebagai penelitian hukum yang doktrinal. Penelitian hukum empiris atau sosiologis adalah metode penelitian yang dilakukan untuk mendapatkan data primer dan menemukan kebenaran dengan menggunakan metode berpikir induktif dan kriterium kebenaran koresponden serta fakta yang digunakan untuk melakukan proses induksi dan pengujian kebenaran secara koresponden adalah fakta yang mutakhir.

\subsection{Sifat Penelitian}

Penelitian ini bersifat deskriptif-analitis. Setelah data terkumpul akan dideskripsikandan di analisa, yang selanjutnya diteruskan dengan upaya untuk menjawab pokok yang diteliti yaitu "Diskresi Kepolisian Melalui Mediasi Penal (Studi Kasus Di Polsek Galur, Kulonprogo)"

11 Ronny Hanitijo Soemitro (1988). Metodologi Penelitian Hukum Dan Jurimetri. Ghalia. Jakarta. hlm.9. 


\subsection{Teknik Pengumpulan Data}

Menurut Soekanto, teknik pengumpulan data terdiri dari studi kepustakaan; pengamatan (observasi), wawancara (interview), dan daftar pertanyaan (kuesioner). ${ }^{12}$

\subsection{Analisis Data}

Adapun analisis data yaitu menggunakan analisis deskriptif kualitatif yaitu data yang diperoleh dianalisis secara kualitatif dan disajikan secara deskriptif. Metode kualitatif adalah suatu tata cara penelitian yang menghasilkan data deskriptifanalisis. ${ }^{13}$ Metode kualitatif adalah metode analisis data yang mengelompokkan dan menyeleksi data yang diperoleh dari penelitian lapangan menurut kualifikasi dan kebenarannya, kemudian dihubungkan dengan teori-teori yang diperoleh dari studi kepustakaan, sehingga akan diperoleh jawaban mengenai rumusan masalah penelitian ini. ${ }^{14}$ Metode analisis secara deskriptif yaitu memilih data yang menggambarkan keadaan yang sebenarnya di lapangan. Dalam analisis menggunakan cara berpikir deduktif, yaitu menyimpulkan hasil penelitian yang khusus. Dengan menggunakan metode tersebut diharapkan dapat memperoleh gambaran yang jelas dan menyeluruh tentang kesesuaian landasan konseptual yang digunakan dalam menjawab pokok permasalahan dalam tesis ini.

\section{Analisis dan Hasil}

\subsection{Mediasi Penal Berdasarkan Diskresi Oleh Kepolisian Resort Kulonprogo Sektor} Galur

Selama ini, keberadaan Polmas di dalam institusi kepolisian khususnya di Polres Kulonprogo Sektor Galur tidak berjalan sendiri, melainkan dibantu oleh berbagai stakeholder di masyarakat, seperti perangkat FPKM, tokoh agama, tokoh masyarakat, tokoh adat, korban dan pelaku sebagai para pihak dalam kasus pidana. Oleh karena itu, keberhasilan Polmas dalam menyelesaikan tugas-tugas sebagai mediator kasus pidana tidak terlepas dari dukungan dari banyak pihak yang memiliki keterkaitan baik langsung maupun tidak langsung. Hal tersebut misalnya diimplementasikan dalam penyelesaian perkara antara Bapak Kasijo dengan kelompok Budidaya Ikan patin di Dusun Sungapan Kidul pada April 2019. Pada kasus yang dialami oleh Pak Kasijo, Bhabinkantibmas Desa Tirtorahayu Aipda Widiyatno berhasil melaksanakan penyelesaian permasalahan antara kedua belah pihak.

Berdasarkan data yang dimiliki oleh Polsek Galur, pada tahun 2019 kasus pidana yang berhasil dimediasi melalui Polmas dan FKM adalah sebagai berikut:

\footnotetext{
12 Soekanto. (1986). Pengantar Peneltian Hukum, Yogyakarta: Universitas Indonesia (UI) Press. hlm.52

13 Soerjono Soekanto dan Sri Mamudji. (2006). Penelitian Hukum Normatif, Raja Grafindo Persada, Jakarta, hlm. 24.

14 Bambang Sunggono. (2003). Metodologi Penelitian Hukum, Raja Grafindo Persada, Jakarta. hlm. 114
} 
Tabel 1

Mediasi Pidana oleh FKM bersama Polmas

\begin{tabular}{|l|c|l|l|}
\hline Bulan & Jumlah & Jenis Kasus \\
\hline Januari & 1 & Pengurus KUD minum miras \\
\hline Februari & 1 & $\begin{array}{l}\text { Penggerebekan tamu lawan jenis tidur di dalam } \\
\text { rumah }\end{array}$ \\
\hline Maret & 1 & $\begin{array}{l}\text { Utang Piutang antara Bp. Sutrisno (Pihak } \\
\text { Pertama) dengan Ibu Siti Khofshoh (Pihak } \\
\text { Kedua) Kan }\end{array}$ \\
\hline April & 1 & $\begin{array}{l}\text { Penipuan oleh Bp. Kasijo (Pihak Pertama) } \\
\text { dengan kelompok tani (Pihak Kedua) }\end{array}$ \\
\hline
\end{tabular}

Sumber: Diolah dari berbagai sumber, 2019

Berdasarkan keempat contoh kasus, proses penyelesaian perkara pidana dilakukan oleh kepolisian dengan bekerjasama dengan FKPM. Pihak Polmas dalam hal ini yang menjadi mediator telah ditunjuk atau diminta oleh para korban atau pelaku seperti dalam kasus 3 dan kasus 4. Pada kasus ini, kepolisian diminta oleh pelapor untuk melakukan mediasi. Sementara untuk kasus 1, dan kasus 2, kepolisian diminta dan bersama dengan masyarakat melakukan mediasi. Dengan demikian, pada kasus 3 dan kasus 4, proses penyelesaian mediasi yang dilakukan oleh kepolisian telah ideal.

Proses penyelesaian pidana dengan jalur mediasi ini pada dasarnya adalah untuk mewujudkan keadilan yang substansial bagi kedua belah pihak. Penyelesaian dilakukan melalui musyawarah. Pihak kepolisian dari Bhabinkantibmas sebagai penegak hukum telah memberikan jalan penyelesaian yang diharapkan. Menurutnya, solusi yang ditempuh dengan jalan musyawarah yang melahirkan kesepakatan tersebut dianggap telah dirasa adil.

Mengupayakan penanganan kasus pidana yang mempunyai kerugian materi kecil, penyelesaiannya dapat diarahkan melalui konsep ADR. ${ }^{15}$ Adapun metode penyelesaian kasus pidana dengan menggunakan metode ADR tidak dapat diputuskan oleh pihak mediator atau pihak ketiga, tetapi harus disepakati oleh masing-masing pihak yang berperkara. Apabila tidak ditemukan kesepakatan dalam proses mediasi, maka penyelesaian selanjutnya dapat ditempuh melalui prosedur hukum yang berlaku secara profesional dan proporsional. Pihak ketiga disini berperan melakukan negosiasi yang bisa diterima pihak yang bersengketa, bukan merupakan bagian dari kedua belah pihak dan bersifat netral. Pihak ketiga tidak mempunyai wewenang untuk mengambil keputusan, karena pihak ketiga dalam hal ini hanya

15 Lihat dalam https://www.hukumonline.com/klinik/detail/ulasan/lt574a375e41718/ bisakah-meminta-polisi-memediasi-masalah-hukum/, diakases pada 2 Januari 2020 
melakukan tugas untuk membantu para pihak yang bersengketa menerima pencapaian kata sepakat secara sukarela ${ }^{16}$. Mediator adalah pihak netral yang membantu para pihak dalam proses perundingan guna mencari berbagai kemungkinan penyelesaian sengketa tanpa menggunakan cara memutus atau memaksakan sebuah penyelesaian ${ }^{17}$. Pada prinsipnya, dalam penyelesaian perkara pidana dengan menggunakan ADR harus berprinsip pada musyawarah mufakat dan harus diketahui oleh masyarakat sekitar dengan menyertakan RT RW setempat. ${ }^{18}$ Penyelesaian kasus pidana dengan menggunakan ADR tidak dilakukan secara kaku, tetapi harus menghormati dan mempertimbangkan norma-norma hukum yang hidup di masyarakat serta memenuhi asas keadilan.

Dalam prosesnya, juga harus memberdayakan anggota Polmas dan memerankan FKPM yang ada di wilayah masing-masing untuk mampu mengidentifikasi kasus-kasus pidana yang mempunyai kerugian materiil kecil dan memungkinkan untuk diselesaikan melalui konsep ADR. Untuk kasus yang telah dapat diselesaikan melalui konsep ADR agar tidak lagi di sentuh oleh tindakan hukum lain yang kontra produktif dengan tujuan Polmas. Adapun mengenai mediator dalam proses mediasi penal, berdasarkan ketentuan yang berlaku, pihak kepolisian telah diberikan kewenangan untuk mengesampingkan perkara pidana atau menyelesaian perkara pidana tanpa meneruskannya ke pengadilan (sarana non litigasi) telah dikenal dalam istem penegakan hukum pidana di Indonesia. Ketentuan mengenai keterlibatan pihak kepolisian dalam proses penanganan perkara pidana diatur dalam Pasal 18 Undang-Undang Nomor 2 Tahun 2002 tentang Polri. Keterlibatan kepolisian dalam menangani perkara pidana dalam proses mediasi dapat menggunakan kewenangan yang diberikan oleh undang-undang yaitu kewenangan diskresi. Diskresi (discretion) yaitu kewenangan kepolisian untuk tidak memproses hukum terhadap tindak pidana sepanjang demi kepentingan umum maupun moral. ${ }^{19}$

Ketentuan yang lebih rinci tentang penggunaan Pasal 18 Undang-Undang Nomor 2 Tahun 2002 tentang Polri yaitu, bahwa kewenangan diskresi tersebut diambil dalam keadaan yang sangat perlu dengan memperhatikan peraturan perundangundangan, serta Kode Etik Profesi Polri. Kepolisian dalam menjalankan ketentuan penjelasan Pasal 18 Undang-Undang Nomor 2 Tahun 2002 tentang Polri, yaitu bertindak menurut penilaian sendiri sebagai suatu tindakan yang dapat dilakukan oleh anggota Polri yang dalam bertindak harus mempertimbangkan manfaat dan

\footnotetext{
${ }^{16}$ Lilik Prihatini. (2015). Perspektif Mediasi Penal Dan Penerapannya Dalam Perkara Pidana.

Pakuan Law Review, Vol.1, No.1, Januari-Juni 2015, pp. 1-46.

${ }^{17}$ Ibid.

18 Lihat dalam https://www.hukumonline.com/klinik/detail/ulasan/lt574a375e41718/ bisakah-meminta-polisi-memediasi-masalah-hukum/, diakases pada 2 Januari 2020

${ }_{19}$ Pasal 18 ayat (1) Undang-Undang Nomor 2 Tahun 2002 tentang Polri menyebutkan bahwa "untuk kepentingan umum pejabat Kepolisian Negara Republik Indonesia dalam melaksanakan tugas dan wewenangnya dapat bertindak menurut penilaiannya sendiri".
} 
risiko serta biaya dan keuntungan (cost and benefit) dari tindakannya yang benar-benar untuk

Selain itu, kewenangan kepolisian dalam menyelesaikan perkara pidana di luar peradilan diatur dalam Pasal 109 ayat (2) Undang-Undang Nomor 8 Tahun 1981 (KUHAP). Dalam ketentuan ini disebutkan bahwa polisi dalam hal ini penyidik dapat menghentikan penyidikan atas perkara tindak pidana karena: (1) tidak terdapat cukup bukti, (2) peristiwa tersebut ternyata bukan merupakan tindak pidana, atau (3) penyidikan dihentikan demi hukum. Dalam rangka menjalankan tugas, Kepolisian Negara Republik Indonesia berwenang untuk mengadakan penghentian penyidikan. Penyidik karena kewajibannya mempunyai wewenang mengadakan penghentian penyidikan.

Dalam hal penyidik menghentikan penyidikan karena ketiga alasan dimaksud, maka penyidik memberitahukan hal ini kepada penuntut umum, tersangka atau keluarganya. Tentunya di sini juga perlu dipikirkan mengenai konsep tentang bagaimana dengan penghentian penyidikan atas dasar diskresi. Oleh karena itu, yang menjadi kesimpulan dari penulis adalah belum adanya kejelasan terkait batasan diskresi dalam kewenangan kepolisian, ${ }^{20}$ sehingga apabila polisi atau penyidik polri dengan menggunakan kewenangan diskresinya dalam menyelesaikan perkara pidana melalui mekanisme mediasi penal, maka yang terjadi adalah polisi atau penyidik tersebut telah melanggar hukum atau setidak-tidaknya telah melangar hukum internalnya (baik peraturan disiplin maupun Kode Etik Profesi Polri).

Apabila mediasi penal (penal mediation) dikaitkan dengan ide keadilan restoratif (restorative justice) dan diskresi (discretion), maka dapat dikatakan bahwa ajaran atau nilai-nilai yang mendasari mediasi penal (penal mediation) adalah restorative justice, sedangkan roh mediasi penal (penal mediation) untuk mewujudkan keadilan restortaif (restorative justice) ada pada tiap-tiap institusi penegak hukum. Mediasi ${ }^{21}$ sebagai salah satu bentuk penyelesaian perkara pidana diluar pengadilan yang merupakan salah satu implementasi dari Restorative Justice. Mediasi penal dipandang sebagai suatu pola penyelesaian perkara yang berakar dari budaya masyarakat tradisional.

\subsection{Dasar dan Kedudukan Diskresi dalam Struktur Kepolisian}

Secara umum mediasi penal diatur melalui Surat Kapolri No Pol: B/3022/XII/2009/ SDEOPS tanggal 14 Desember 2009 tentang Penanganan Kasus Melalui Alternatif Dispute Resolution (ADR) dan Peraturan Kapolri Nomor 7 Tahun 2008 Tentang Pedom an Dasar Strategi dan Implementasi Pemolisian Masyarakat Dalam Penyelenggaraan Tugas Polri. Selanjutnya kewenangan Polmas untuk melakukan mediasi merupakan implementasi dari Surat Telegram Kabareskrim Polri

\footnotetext{
20 Pasal 18 Undang-Undang Nomor 2 Tahun 2002

${ }^{21}$ Bejo Suryo Hadi Purnomo. (2018). Kedudukan Mediasi Penal Dalam Sistem Peradilan Pidana di Indonesia. Jurnal Ilmiah Ilmu Sosial, Vol.4, No.2, Desember 2018, pp. 187-199.
} 
No. Pol.: STR/583/VIII/2012 yang di tujukan kepada para Kapolda, Dirreskrimum, Dirreskrimsus dan Dirresnarkoba di seluruh wilayah Indonesia. Berdasarkan Surat Telegram Kabareskrim Polri, bahwa kepolisian dalam menjalankan tugas-tugas penegakan hukum tidak menutup kemungkinan untuk menempuh jalur non-litigasi melalui mediasi. Hal tersebut merupakan upaya pihak kepolisian untuk menerapkan restorative justice dengan mengutamakan asas kemanfaatan dan keadilan hukum bukan pendekatan kepastian hukum.

Theory of Restorative Justice menyatakan bahwa peradilan lebih menekankan pada perbaikan kerusakan yang disebabkan atau ditimbulkan oleh suatu tindak pidana (repairing the harm caused or revealed by criminal behavior) ${ }^{22}$. Menurut Susan Sharpe ${ }^{23}$, sebagaimana dikutip oleh Natangsa Surbakti, restorative justice menempatkan keputusan kunci penyelesaian perkara pada korban sebagai pihak yang paling terpengaruh oleh kejahatan yang terjadi, sehingga pihak korban harus dilibatkan dalam proses penyelesiaan perkara. Dengan demikian dalam proses peradilan ini mengupayakan agar peradilan dapat memulihkan atau menyembuhkan dan memperbarui keadaan, serta menghilangkan kemungkinan terjadinya pengulangan pelanggaran yang sejenis. Secara umum upaya-upaya yang dilakukan untuk mencapai tujuan peradilan restorative dalam penyelesaian perkara pidana antara lain: (1) pengidentifikasian dan pengambilan Langkah-langkah untuk memperbaiki kerusakan; (2) pelibatan semua pihak yang memiliki peran (stakeholders); dan (3) pendayagunaan hubungan tradisional antara masyarakat dan pemerintahan dalam menanggulangi kejahatan ${ }^{24}$.

Selain korban kejahatan, peradilan restorative juga melibatkan pelaku kejahatan, dalam hal ini agar kedua belah pihak sama-sama mencapai "keterbukaan" dan kedua pihak dapat berintegrasi seperti sedia kala di lingkungannya. Pelaku diharapkan supaya memahami perbuatannya telah mempengaruhi orang lain dan membawa tuntutan tanggung jawab atas perbuatan itu ${ }^{25}$. Mark William Baker menyatakan bahwa mediasi penal adalah "mediation was the practice to put victims and criminals together and reach a reciprocal understanding on restitution ${ }^{26 . "}$

Perkara pidana menurut Hukum Acara Pidana, pada prinsipnya tidak dapat diselesaikan di luar pengadilan, walaupun dalam hal-hal tertentu. Akantetapi dalam hal delik yang dilakukan berupa "pelanggaran yang hanya diancam dengan pidana denda" dimungkinkan adanya penyelesaian di luar pengadilan. Ketika terdakwa telah membayar denda maksimum untuk delik pelanggaran itu dan biaya-biaya yang telah dikeluarkan kalau penuntutan, maka kewenangan/hak menuntut delik pelanggaran itu hapus (Pasal 82 KUHP). Pembayaran denda ini menurut ketentuan dalam Pasal 82

\footnotetext{
${ }^{22}$ Natangsa Surbakti. (2011). Mediasi Penal Sebagai Terobosan Alternatif Perlindungan Hak. Jurnal Ilmu Hukum, Vol. 14, No. 1, Maret 2011, pp. 90 -106.

${ }^{23} \mathrm{Ibid}$.

${ }^{24} \mathrm{Ibid}$

${ }^{25} \mathrm{Ibid}$

${ }^{26}$ Lilik Prihatini, op. cit.
} 
KUHP disebut dengan istilah "afkoop" atau "pembayaran denda damai" yang merupakan salah satu alasan penghapus penuntutan27. Menurut Barda Nawawi Arief, pemberian ganti rugi merupakan "sarana pengalihan atau diversi" (means of diversion)" untuk dihentikannya penuntutan maupun penjatuhan pidana ${ }^{28}$.

Penyelesaian perkara pidana di luar pengadilan juga dapat dilaksanakan dalam hal tindak pidana dilakukan oleh anak di bawah usia 8 tahun. Kategori anak nakal menurut UU Pengadilan Anak ( UU No. 3/1997), yang kasusnya dapat diajukan ke pengadilan adalah sekurang-kurangnya 8 tahun dan belum mencapai 18 tahun. Kejahatan yang dilakukan oleh anak di bawah 8 tahun, menurut Pasal 5 UU Pengadilan Anak, Penyidik dapat menyerahkan kepada Departemen Sosial apabila dipandang tidak dapat lagi dibina oleh orang tua/wali/orang tua asuh atau kepada orang tua, wali, atau orang tua asuhnya apabila dipandang masih dapat dibina ${ }^{29}$.

Dengan melihat karakter masyarakat desa, mediasi memang merupakan cara yang tepat untuk menyelesaikan perkara pidana, mengingat prinsip penting dalam mediasi penal adalah adanya pengakuan kesalahan dan pemberian maaf oleh pihak yang dirugikan dan mediasi penal dapat dilakukan jika para pihak yang terlibat dalam perudingan saling menyadari dan menghargai terhadap hasil yang diperoleh ${ }^{30}$. Bertolak dari hal tersebut, perpolisian masyarakat bidang Reskrim dan Bhabinkamtibmas di Polres Kulonprogo Sektor Galur dalam menjalankan tugas penegakan hukum ditugaskan untuk menciptakan penegakan hukum di bidang pidana. Berdasarkan hasil penelitian bahwa tugas penegakan hukum tetap dipegang oleh Kepolisian, sementara keberadaan Polmas di dalam struktur organisasi kepolisian hanya menjalankan tugas khusus yang bukan menjadi tugas Kepolisian secara normatif. Bhabinkamtibmas dalam menjalankan tugasnya bekerjasama dengan tokoh agama (Toga), tokoh masyarakat (Tomas) dan perangkat lain serta masyarakat dalam pencarian informasi berkaitan dengan tindak pidana yang dilakukan oleh warga binaanya. Informasi tersebut kemudian ditindaklanjuti dan disikapi serta diselesaikan melalui mediasi antar pihak.

Pelibatan langsung perpolisian masyarakat ke dalam dalam struktur kerja Polres Kulonprogo Sektor Galur selama ini telah membantu tugas-tugas kepolisian khususnya dalam menekan dan menyelesaikan permasalahan hukum tindak pidana yang dilakukan oleh masyarakat di wilayah hukum Polres Kulonprogo Sektor Galur. Aktivitas perpolisian masyarakat misalnya terlihat dalam tindak pidana penipuan, kejahatan terhadap perempuan, hutang piutang, miras KUD dan tindak pidana lainnya.

Keberadaan perpolisian masyarakat dalam struktur kerja Polres Kulonprogo Sektor Galur menjadi bagian dari strategi kepolisian untuk dalam meminimalisir

\footnotetext{
${ }^{27}$ Barda Nawawi Arief, op. cit., hlm. 35.

28 Ibid.

${ }^{29} \mathrm{Ibid}$.

${ }^{30}$ Bejo Suryo Hadi Purnomo, op. cit.
} 
angka kejahatan secara umum. Kerja-kerja perpolisian masyarakat dalam mengurangi kejahatan tersebut dirasakan langsung oleh bagian reskrim. Hal tersebut ditunjukkan dengan menurunnya angka kejahatan yang ditangani langsung oleh reskrim.

Selain dapat menekan angka kejahatan dengan meredam kejahatan-kejahatan potensial dan atau potensi kejahatan yang akan terjadi, aktivitas kerja Polmas juga terlibat dalam memediasi kasus-kasus pidana yang ada di wilayah hukum Polres Kulonprogo Sektor Galur. Polmas berperan dalam penyelesaian kasus pidana melalui pendekatan restorative justice dengan melakukan mediasi penal sebagaimana disebutkan dalam hasil wawancara berikut ini: "Peran Polmas dalam mediasi kasus dengan prinsip penyelesaian kasus dengan pendekatan restorative justice, mediasi penal dan pendekatan community policing yang menjadi dasar penyelesaian kasus melalui FKPM adalah mendekonstruksi tindak pidana menjadi permasalahan sosial / permasalahan yang melibatkan para pihak" 31 . Sebenarnya metode mediasi penal yang dilaksanakan oleh Polmas sejalan dengan metode musyawarah mufakat yang berakar dari kearifan lokal masyarakat adat dalam penyelesaian perkara, dengan tidak membedakan antara permasalahan yang dalam bidang hukum privat atau permasalahan yang masuk dalam hukum publik secara jelas ${ }^{32}$.

Menurut Jeff Knight, dalam penyelenggaraan peradilan restorative melalui proses musyawarah, selalu diarahkan tercapainya kepuasan bagi semua pihak, dan dapat diwujudkan oleh si pelaku tindak pidana. Kesepakatan-kesepakatan yang dihasilkan melalui musyawarah lazimnya memuat beberapa hal berikut: (1) permintaan maaf dari pelaku kepada korban; (2) melakukan berbagai pekerjaan tak berbayar kepada pihak korban; (3) memberikan kompensasi finansial kepada korban; (4) melakukan pekerjaan sukarela untuk organisasi sosial; (5) memberikan santunan berupa uang untuk kepentingan sosial; (6) memberikan pertolongan pertama pada saat kejadian; dan (7) menaati kesepakatan dengan sepenuh hati33.

Penyelesaian kasus-kasus dengan cara mediasi dengan berdasar pada restorative justice, mediasi penal dan pendekatan community oriented policing (COP), ditandai dengan rambu-rambu perkara yang menjadi wewenang FKPM yang diatur secara limitatif dalam Surat Keputusan Kapolri No. 433 Tahun 2006 oleh pengurus FKPM. Pada dasarnya mediasi adalah cara penyelesaian sengketa di luar pengadilan melalui perundingan yang melibatkan pihak ketiga yang bersikap netral dan impartial terhadap para pihak yang bersengketa serta diterima kehadirannya oleh para pihak yang bersengketa ${ }^{34}$. Pihak ketiga yang dimaksud ini seperti tokoh-tokoh masyarakat setempat, tokoh agama ataupun tokoh adat serta aparat pemerintahan tingkat lokal Proses penyelesaian kasus-kasusnya dilakukan secara kekeluargaan melalui musyawarah mufakat atau dengan cara perdamaian. Keputusan dalam mediasi dapat

${ }^{31}$ Wawancara dengan Bapak Eko Cahyono/Kelik/Hardi Ketua FPKM Kecamatan Galur pada 23 Mei 2019, pukul 10.00 WIB.

32 Bejo Suryo Hadi Purnomo, op. cit.

${ }^{33}$ Natangsa Surbakti, op. cit.

${ }^{34}$ Lilik Prihatini, op.cit. 
berupa perkara dianggap selesai sepenuhnya, berarti perkara tidak berlanjut pada pemeriksaan di sidang pengadilan ${ }^{35}$.

3.3. Faktor Pendukung dan Penghambat Pelaksanaan Mediasi Pidana oleh Kepolisian Resor Kulonprogo, Sektor Galur Melalui Institusi Perpolisian Masyarakat

\subsubsection{Faktor Pendukung}

Pertama, Peraturan Perundangan; Salah satu yang menjadi rujukan dalam pelaksanaan kewenangan diskresi adalah Undang-Undang Nomor 2 tahun 2002 tentang Kepolisian Negara Republik Indonesia (UU Polri). UU Polri mengatur secara tegas tentang kepolisian meskipun belum secara terperinci dan masih terdapat kekurangankekurangan, tapi dirasa telah cukup membantu polisi dalam memberikan pedoman pada saat pelaksanaan segala tugas, kewajiban dan wewenangnya dalam penegakan hukum.

Kedua, Petugas Penyidik; Peran dan kedudukan polisi sebagai seorang penyidik telah memberikan wewenang pada polisi tersebut untuk melakukan diskresi, sehingga petugas penyidik tersebut dapat mempergunakan diskresi dalam melaksanakan tugasnya. Hal ini juga dapat menjadi faktor pendorong diskresi, karena penyidik tersebut memang telah memiliki wewenang untuk melakukannnya. Ditinjau dari sudut penilaian petugas penyidik, maka sebelum dilakukan diskresi pada saat penyidikan petugas itu akan mengukur atau mempertimbangkan tindakan tersebut.

\subsubsection{Faktor Penghambat}

Pertama, Sarana dan Prasarana; Sarana dan prasarana merupakan hal yang sangat vital untuk mendukung tugas-tugas kepolisian. Kinerja kepolisian dalam menegakkan hukum tidak akan berhasil tanpa dukungan sarana dan prasarana, walaupun pada dasarnya penegakan hukum bergantung pada unsur manusia. Tetapi, unsur manusia tidak akan berhasil dengan baik tanpa dilengkapi dengan sarana atau fasilitas yang mendukung pelaksanaan diskresi.

Kedua, Dukungan Masyarakat; Kinerja kepolisian tidaklah berdiri sendiri, melainkan membutuhkan dukungan dari pihak lain dalam hal ini adalah masyarakat. Penggunaan kewenangan diskresi sebagai kewenangan yang tidak biasa membutuhkan dukungna masyarakat. Kepolisian dalam menjalankan kewenangan tersebut dipengaruhi oleh situasi orang lain, kelompok orang atau masyarakat menurut anggapan atau penilaian petugas dalam penegakan hukum. Namun demikian, dalam masalah diskresi polisi membutuhkan keyakinan sendiri terhadap permasalahan yang dihadapi dengan berlandaskan pada pertimbangan-pertimbangan logis.

Ketiga, Faktor budaya; Kewenangan diskresi sebagai tindakan yang tidak biasa yang diberikan kepada kepolisian tidak akan sukses tanpa dukungan seluruh nilai-nilai

\footnotetext{
35 Natangsa Surbakti, op. cit.
} 
yang hidup di dalam masyaakat. Pelaksanaan Diskresi Kepolisian tidak untuk memenuhi kepentingan pribadi, kelompok atau organisasi melainkan harus dapat mengakomodir kepentingan umum, keadilan, kemanusiaan yang terjadi pada situasi atau kondisi yang bersifat mendesak serta harus didasari dengan hati nurani, etika profesi dan moral.

Keempat, Struktur Institusi Kepolisian; Selain faktor yang mempengaruhi diskresi tersebut, ada faktor yang dapat menghambat petugas penyidik untuk melakukan diskresi adalah: Kendala struktural yang menghambat berupa anggaran yang terbatas, karena dana yang tersedia yang berasal dari dinas untuk penyidikan, penyamaran, maupun penangkapan yang dilakukan oleh penyidik tidak memadai dari keseluruhan biaya kegiatan tersebut dan selebihnya adalah dana swadaya dari penyidik sendiri. Sehingga dana yang dapat digunakan untuk keperluan proses panyidikan sangat terbatas.

Setiap permasalahan yang sudah masuk kedalam penyidikan harus dicarikan bagaiman solusinya, apakah dilanjutkan atau diambil cara lain dengan diskresi. Sekalipun diambil dengan tindakan diskresi oleh polisi hal itu tetap saja memerlukan biaya karena perkara sudah terlanjur masuk kedalam proses, hanya saja sedikit lebih ringan dibandingkan jika diteruskan. Hal ini membawa akibat polisi memberikan diskresi terhadap masalah sebagai jalan keluar agar tidak terjadi pembengkakan biaya. Dengan anggaran yang serba terbatas tersebut seharusnya tidak mengurangi kualitas diskresi yang diberikan oleh polisi, justru dengan diskresi itu diharapkan terdapat prioritas agar perkara yang serius saja yang diproses sedangkan perkara ringan yang kurang berarti tidak menambah berat beban polisi dalam penyidikan.

Polisi professional adalah polisi yang mampu melaksanakan tugasnya sesuai dengan kapasitas pendidikan yang diterimanya sekaligus mampu menggunakan instrumen-instrumen hasil pengembangan ilmu pengetahuan. alam hubungannnya dengan diskresi, polisi yang kurang profesional itu membawa akibat mutu diskresi yang diberikan pada saat penyidikan juga kurang berkualitas. Hal ini diakibatkan dalam menentukan masalah yang dapat dilakukan diskresi terdapat keterbatasan pemahaman karena masih minimnya profesionalitas dan keahlian tadi, Sehingga profesionalisme dan keahlian polisi dalam menangani suatu masalah dan mengambil kebijakan termasuk diskresi menjadi kunci penentu berkualitas atau tidaknya hasil akhir kebijakan tersebut..

Masih lemahnya hukum di Indonesia dalam hal diskresi salah satu contohnya adalah hubungan yang seharusnya bersifat resmi yang seharusnya sesuai dengan aturan hukum yang ada tetapi dianggap sebagai hubungan kekeluargaan. Hal seperti ini menempatkan polisi pada posisi yang serba salah, karena perasaan kekeluargaan menjadikan diskresi seperti penyaringan perkara, penghentian penyidikan sebagai suatu kewajiban bukan lagi sebagai alternatif yang diberikan oleh hukum agar efisien. Akibatnya keadilan tidak bisa diciptakan dan ditegakkan, karena diskresi tadi seolah- 
olah telah menciptakan diskriminasi bagi sebagian orang saja, yaitu untuk diskresi dibandingkan dengan masyarakat biasa.

Pemahaman masyarakat yang kurang terhadap diskresi menyebabkan juga kurangnya partisipasi masyarakat terhadap kepolisian juga menjadikan kerja polisi sedikit berat. Selain hal itu anggapan dari masyarakat bahwa diskresi adalah suatu hal yang buruk karena termasuk pelanggaran hukum, juga membawa akibat bagi polisi sulit untuk leluasa menggunakan diskresi terhadap masalah yang memang seharusnya menurut hukum jalan keluarnya dan dengan didiskresikan, dalam arti bila polisi menggunakan wewenang diskresinya maka masyarakat menganggap polisi itulah yang justru melakukan pelanggaran hukum karena tidak menindak pelaku kejahatan tetapi justru memberikan kesempatan untuk bebas dari tuduhan dengan dalih diskresi tadi.

\subsection{Pola Ideal Mediasi Penal}

Dalam penanganan kasus pidana, sekilas mediasi penal hampir sama dengan diskresi (discretion) yang dimiliki oleh lembaga sistem peradilan pidana Indonesia, seperti Kepolisian dan Kejaksaan untuk menyaring kasus-kasus yang masuk untuk tidak meneruskan sebagian kasus tertentu melalui proses peradilan pidana. Namun demikian terdapat esensi yang berbeda dengan sistem diskresi tersebut.

Mediasi penal lebih mengedepankan kepentingan pelaku tindak pidana dan sekaligus kepentingan korban, sehingga tercapai win-win solution yang menguntungkan pelaku tindak pidana dan korbannya. Dalam mediasi penal korban dipertemukan secara langsung dengan pelaku tindak pidana dan dapat mengemukakan tuntutannya sehingga dihasilkan perdamaian para pihak. Mediasi penal dilakukan dengan transparan sehingga dapat mengurangi permainan kotor yang seringkali terjadi dalam proses peradilan pidana tradisional. Mengingat banyaknya keuntungan yang ada pada mediasi penal, sebagaimana telah dipraktikan di beberapa negara, maka diperlukan upaya berupa kajian untuk menerapkan mediasi penal dalam proses peradilan pidana Indonesia sebagai bagian dari sistem peradilan pidana di Indonesia.

Menurut Stephen R. Covey penyelesaian secara win-win solution berarti semua orang untung, karena kesepakatan atau pemecahan masalahnya menguntungkan dan memuaskan kedua belah pihak. Dengan pemecahan yang menang-menang, semua pihak merasa senang terhadap keputusan yang diambil serta terikat untuk ikut melaksanakan rencana tindakan yang telah disepakati. Penyelesaian secara win-win solution dimaksudkan bahwa para pihak rela untuk bekerjasama dengan pihak lain menempuh cara-cara yang menjamin keberhasilan bersama, serta memungkinkan semua orang menjadi pemenang. Hakikat sikap menang-menang adalah akan memperlancar interaksi sesama, dan akan menghasilkan kesepakatan serta pemecahan masalah yang memungkinkan semua pihak memperoleh apa yang diinginkan ${ }^{36}$.

\footnotetext{
${ }^{36}$ Stephen R. Covey. (1989). The Seven Habits of Highly Effecive People, Powerful Lesson in Personal Change. USA, Free Press.
} 
Mediasi penal merupakan salah satu aspek pembaharuan hukum pidana sebagaimana ditetapkan dalam Konferensi Internasional Pembaharuan Hukum Pidana (International Penal Reform Conference) Tahun 1999. Dalam konferensi tersebut diputuskan bahwa sistem peradilan pidana formal harus diperkaya dengan sistem peradilan pidana informal yang sesuai dengan standar hak asasi manusia, dengan melalui pengembangan restorative justice, alternative disputeresolution, informal justice, alternatives to custody, alternative ways of dealing with juveniles, dealing with violent crime, reducing the prison population, the proper management of prisons, and the role of civil in penal reform ${ }^{37}$.

Pada Konggres PBB tahun 2000, ditetapkan legal framework bagi pelaksanaan mediasi penal dan restorative justice yaitu the Recommendation of the Council of Eure 1999 No. R (99) 19 tentang "Mediation in Penal Mattres", yang ditindaklanjuti oleh Uni Eropa pada tahun 2001 dengan menetapkan The Europe Union Framework Decision 2001: The Stannding of Victim in Criminal Proceedings. Dan pada tahun 2002 secara resmi PBB menetapkan The UN Principles 2002 (Resolusi Ecosoc 2002/12) tentang "Basic Principles on the Use Restorative Justice Programmes in Criminal Matters".

Mendasarkan pada legal framework yang ditetapkan oleh PBB, beberapa negara seperti Negara Austria, Jerman, Belgia, Perancis dan Polandia menetapkan legal framework bagi mediasi penal untuk penyelesaian perkara pidana. Tony Peters mengemukakan "legal framework" di beberapa negara Eropa ditempatkan dalam legal framework yang berbeda, paling tidak dari hasil kajiannya, ada 4 legal framework yang dipraktekkan oleh negara-negara di dunia ${ }^{38}$. Pertama, mediasi penal ditempatkan sebagai bagian dari UU Peradilan Anak, yaitu di Austria, Jerman, Finlandia, dan Polandia. Kedua, ditempatkan dalam KUHAP, seperti negara Austria, Belgia, Finlandia, Perancis, dan Polandia. Ketiga, dalam KUHP, seperti Finlandia, Jerman, dan Polandia. Keempat, mediasi penal diatur sendiri secara otonom dalam suatu undang-undang, seperti di Norwegia ${ }^{39}$. Indonesia sendiri, mediasi penal sebagai salah satu bentuk alternatif penyelesaian sengketa di luar pengadilan telah diatur dalam UndangUndang Nomor 30 tahun 1999 tentang Arbitrase dan Alternatif Penyelesaian Sengketa. Bahkan di Nanggroe Aceh Darussalam ${ }^{40}$, telah menetapkan Peraturan Daerah Nomor 7 tahun 2000 tentang Penyelenggaraan Kehidupan Adat, dimana memuat ketentuan mengenai sengketa masyarakat diselesaikan secara damai melalui musyawarah mufakat terlebih dahulu, sebelum perkara diserahkan ke apparat penegak hukum. Memang sebenarnya mediasi penal merupakan salah satu ciri khas hukum adat, tujuannya adalah untuk menyelesaikan konflik, memulihkan keseimbangan dan

\footnotetext{
37 Bejo Suryo Hadi Purnomo, op. cit.

38 Barda Nawawi Arief. (2008). Mediasi Penal Penyelesaian Perkara di luar Pengadilan. Semarang: Pustaka Magister.

39 Bejo Suryo Hadi Purnomo, op. cit.

40 Ibid.
} 
mendatangkan rasa damai. Dapat dikatakan bahwa penyelesaian damai kasus pidana sudah merupakan kearifan lokal di berbagai daerah dan hukum adat di Indonesia ${ }^{41}$.

Dalam perspektif pembaharuan hukum pidana, kebijakan mediasi penal dalam dapat dikontribusikan melalui dua cara atau bentuk, yaitu bentuk mediasi penal di luar proses peradilan pidana yakni melalui lembaga adat desa atau lembaga kemasyarakatan desa dengan melalui mekanisme perundingan atau musyawarah. Mediator terdiri atas unsur struktur adat atau struktur desa. Sedangkan bentuk yang kedua adalah bentuk mediasi penal sebagai bagian dari proses sistem peradilan pidana (SPP) dimana dapat dimediasi dari tahap penyidikan oleh penyidik, penuntutan oleh penuntut umum, pengadilan oleh hakim atau pelaku menjalankan pidana penjara oleh lembaga pemasyarakatan ${ }^{42}$.

Implementasi media penal dalam pembaharuan sistem peradilan pidana menjadi urgen, dikarenakan oleh beberapa hal berikut, yaitu dengan diterapkannya mediasi penal diharapkan dapat mengurangi penumpukan perkara; mediasi penal merupakan salah satu proses penyelesaian sengketa yang dianggap lebih cepat, murah dan sederhana, dan dapat memberikan akses seluas mungkin kepada para pihak yang bersengketa untuk memperoleh keadilan; serta mediasi penal akan memperkuat dan memaksimalkan fungsi lembaga pengadilan dan penyelesaian sengketa di samping proses menjatuhkan pemidanaan ${ }^{43}$.

Dari sudut pandang sosiologis, sebenarnya mediasi penal lebih berorientasi pada akar budaya masyarat Indonesia yang berlandaskan nilai budaya kekeluargaan, yakni dengan mengkedepankan asas musyawarah mufakat untuk menyelesaikan suatu sengketa dalam suatu sistem sosial. Penyelesaian sengketa yang muncul di masyarakat diselesaikan melalui dimensi kearifan lokal hukum adat ${ }^{44}$. Selanjutnya untuk dapat melaksanakan bentuk mediasi penal di luar proses peradilan pidana yang dilakukan oleh lembaga adat desa atau lembaga kemasyarakatan desa, dibutuhkan beberapa landasan hukum berupa aturan hukum yang menetapkan tentang: (1) tindak pidana yang dapat dimediasikan; (2) mediasi penal yang dilakukan oleh pihak pelaku dan korban di luar pengadilan terhadap tindak pidana tertentu diakui keabsahannya jika dilakukan secara suka rela; (3) mediasi penal difasilitasi oleh mediator, dalam hal ini oleh struktur adat atau struktur desa); (4) kekuatan hukum hasil kesepakatan yang dicapai oleh pihak pelaku dan korban, sebagai keputusan yang sah dan final sehingga tidak dapat diganggu gugat dan tidak perlu dikuatkan melalui penetapan pengadilan cukup apabila disahkan dengan materai dan tanda tangan semua pihak; dan (5) hasil

${ }^{41}$ Rudini Hasyim Rado, Barda Nawawi Arief, Eko Soponyono. op. cit.

${ }^{42}$ Ibid.

${ }^{43}$ Dwiasih Nadyanti, Putri Nabila K. A., Tiara Jayaputeri. Urgensi Penerapan Mediasi Penal Sebagai Alternatif Penyelesaian Perkara Pidana Ringan Di Luar Pengadilan. Adil: Jurnal Hukum Vol. 9 No.2, pp. 100-117.

${ }^{44}$ Lilik Mulyadi, Mediasi Penal Dalam Sistem Peradilan Pidana Indonesia: Pengkajian Asas, Norma, Teori dan Praktek, Yustisia, Vol.2 No.1 Januari-April 201, pp. 1-14. 
kesepakatan yang dicapai dalam mediasi penal sebagai alasan hapusnya penuntutan tindak pidana ${ }^{45}$.

Sistem peradilan pidana merupakan sistem yang terdiri atas sub-sub sistem seperti lembaga kepolisian, lembaga kejaksaan, lembaga pengadilan dan lembaga pemasyarakatan, bahkan termasuk penasihat hukum. Dalam bekerjanya sistem peradilan pidana Indonesia berlandaskan pada Undang- Undang Nomor 8 Tahun 1981 tentang Kitab Undang-Undang Hukum Acara Pidana (KUHAP), sebagai hukum formil untuk melaksanakan hukum pidana materiil. Dalam proses peradilan pidana, bekerjanya sistem peradilan pidana terdapat saling kebergantungan (interdepency) antara sub sistem satu dengan sub sistem lainnya.

Mediasi penal merupakan salah satu bentuk dari pelaksanaan restorative justice, yaitu konsep yang memandang kejahatan secara lebih luas. Konsep ini memandang bahwa kejahatan atau tindak pidana bukanlah hanya sekedar urusan pelaku tindak pidana dengan negara yang mewakili korban, dan meninggalkan proses penyelesaiannya hanya kepada pelaku dan negara (Jaksa penuntut umum). Penyelesaian tindak pidana di luar proses peradilan pada dasarnya merupakan proses penyelesaian perkara tindak pidana yang memposisikan pelaku tindak pidana dengan korban dalam level yang sama dan penyelesaiannya dengan cara kesepakatan oleh para pihak di luar kewenangan Pengadilan dengan realisasi pihak ketiga ${ }^{46}$. Pada prinsipnya penyelesian perkara pidana melalui mediasi penal adalah untuk memadukan ide keseimbangan antara perlindungan kepentingan pelaku dengan perlindungan kepentingan korban ${ }^{47}$. Mediasi penal hanya dapat dilakukan apabila para pihak yang terlibat dalam perudingan saling menyadari dan menghargai terhadap hasil yang diperoleh, prinsip yang terpenting dalam mediasi penal adanya pengakuan kesalahan dan pemberian maaf oleh pihak yang dirugikan akibat tindak pidana untuk mencapai penyelesaian saling menguntungkan ${ }^{48}$. Dengan demikian pemidanaan dalam mediasi penal bertujuan untuk mendidik kembali terpidana mematuhi aturan kebiasaan masyarakat atau membangun sikap yang patut terhadap aturan hidup bersama/bermasyarakat. Dengan demikian penyelesaian dengan mediasi penal tidak hanya untuk menegakkan atau membangun "rule of the law" saja, melainkan juga "rule of social cohabitation" 49. Dengan demikian, tujuan akhir Mediasi Penal sebagai upaya Penyelesaian perkara pidana di luar proses peradilan, adalah bahwa perkara pidana tidak harus dengan pemidanaan atau penjatuhan sanksi pidana, melainkan sebagai sarana pembinaan untuk menanggulangi masalah-masalah sosial ${ }^{50}$.

\footnotetext{
${ }^{45}$ Ibid.

46 Taufiqurrohman Abildanwa. (2016). Mediasi Penal Sebagai Upaya Dalam Rangka Pembaharuan Hukum Pidana di Indonesia Berbasis Nilai-Nilai Keseimbangan. Jurnal Pembaharuan Hukum, Vol.3 No. 1 Januari - April 2016, pp. 138-148.

47 Ibid.

48 Sahuri Lasmadi, op. cit.

${ }^{49}$ Taufiqurrohman Abildanwa, op. cit.

50 Ibid.
} 
Lembaga Kepolisian mempunyai kewenangan untuk menentukan apakah suatu perbuatan diteruskan atau tidak diteruskan dalam proses peradilan pidana dengan alasan-alasan tertentu. Dalam perkara lalu lintas misalnya dalam kecelakaan lalu lintas, apabila hanya menimbulkan kerugian yang kecil atau luka yang kecil biasanya diselesaikan dengan mediasi di antara pelaku dan korban, dan pihak kepolisian sebagai saksi atas kesepakatan yang dicapai, perkara tidak diteruskan atas dasar kesepakatan bersama antara pelaku dan korban.

Kategori ruang lingkup perkara yang dapat diselesaikan melalui mediasi penal menurut Mudzakkir ada 7, yaitu pelanggaran hukum pidana: (1) kategori delik aduan, baik aduan yang bersifat absolut maupun relatif. (2) kategori menurut Pasal 80 KUHP, pembayaran ganti rugi. (3) kategori "pelanggaran", bukan "kejahatan", yang hanya diancam dengan pidana denda. (4) tindak pidana di bidang hukum administrasi yang menempatkan sanksi pidana sebagai ultimum remedium. (5) kategori ringan/serba ringan dan aparat penegak hukum menggunakan wewenangnya untuk melakukan diskresi. (6) biasa yang dihentikan atau tidak diproses ke pengadilan (deponir) oleh Jaksa Agung sesuai dengan wewenang hukum yang dimilikinya. (7) kategori pelanggaran hukum pidana adat ${ }^{51}$.

Dalam hasil penelitian dijumpai kasus dimana pelaku memberikan ganti kerugian kepada korban. Kesepakatan mengganti kerugian pada dasarnya tidak menghapuskan tindak pidananya, karena pelaku tetap saja disidik dan diproses dalam sistem peradilan pidana. Proses mediasi penal yang dilakukan oleh lembaga kepolisian dalam tindak pidana tertentu, bukanlah bentuk diskresi kepolisian, karena dalam diskresi kepolisian keputusan yang diambil justru bertentangan dengan peraturan sehingga melalui pertimbangan yang sangat banyak dan strategis untuk kepentingan orang banyak. Di sini pun peran polisi bukan sebagai mediator, melainkan hanya sebagai saksi yang menyaksikan diselesaikannya perkara pidana tersebut melalui kesepakatan perdamaian. ${ }^{52}$

Dalam kasus mediasi tindak pidana, bentuk pidana tidak hanya terdiri atas tindak pidana dalam bentuk delik aduan. Namun di samping delik aduan biasanya masyarakat menyelesaikan sendiri perkara pidana dengan mediasi yaitu misalnya dalam tindak pidana kekerasan dalam rumah tangga (KDRT), sekali pun tindak pidana yang dilakukan oleh pelaku bukan merupakan delik aduan, akan tetapi berdasarkan alasan untuk kepentingan semua pihak dan keutuhan rumah tangga maka penyelesaian secara mediasi seringkali menjadi pilihan. Dalam mediasi pihak korban dapat meminta ganti kerugian kepada pelaku, namun demikian apabila terjadi kesepakatan dari pihak korban dan pelaku untuk mengganti kerugian,

${ }^{51}$ Mudzakkir. (2007). “Alternative Dispute Resolution (ADR): Penyelesaian Perkara Pidana Dalam Sistem Peradilan Pidana Indonesia". Makalah Workshop, Jakarta,18 Januari 2007.

52 Romli Atmasasmita. (2008). "Sinergi Kerja Polri Dan Kejaksaan Agung Dalam Sistem Peradilan Pidana di Indonesia," Makalah disampaikan pada Seminar Hubungan Polisi - Jaksa: Menuju Integrasi, di Auditorium Bumi Putera -Fakultas Ilmu Sosial dan Ilmu Politik Univ. Indonesia, Depok, 17 April 2008 
kesepakatannya tidak menghilangkan penuntutan, sehingga proses peradilan tetap berjalan sebagaimana mestinya, dan kesepakatan ganti kerugian hanya bersifat sebagai pertimbangan jaksa dalam mengadakan penuntutan, keputusan tetap di tangan hakim.

Mediasi penal di sini hanya bersifat memperingan tuntutan, oleh karena belum ada undang-undang yang mengatur pelaksanaan mediasi beserta kekuatan hukum dari akte kesepakatan hasil mediasi penal. Jadi pelaku tetap dipidana akan tetapi pidananya diperingan. Sementara itu dalam menangani kasus tindak pidana yang masuk ke dalam katagori 'delik biasa', seperti kasus-kasus yang mengandung unsur kelalaian seperti dalam Pasal 359 KUHP (karena kelalaiannya menyebabkan matinya orang lain), serta dalam tindak pidana terhadap harta benda seperti Pasal 372 KUHP tentang penggelapan dan Pasal 378 tentang penipuan yang biasanya antara korban dan pelaku sudah saling mengenal, maka dapat dilakukan mediasi di mana korban dapat meminta ganti kerugian kepada pelaku dengan sebuah akta kesepakatan bahwa telah dilakukan pembayaran ganti kerugian kepada korban.

Namun demikian meskipun telah dilakukan kesepakatan mengganti kerugian kepada korban, proses penuntutan terhadap pelaku tindak pidana tetap dilakukan, dengan alasan kejaksaan bekerja berdasarkan aturan normatifnya, selama belum ada aturan yang mengatur kedudukan mediasi penal dalam penuntutan berarti kasus tetap diproses, namun karena telah dilakukan pembayaran ganti kerugian, alasan tersebut hanya menjadi salah satu alasan pertimbangan Jaksa Penuntut untuk memperingan maksimum tuntutannya.

Dalam hukum pidana tidak dikenal mediasi penal, namun demikian ada kesempatan bagi korban untuk menggugat ganti kerugian kepada pelaku melalui gugatan perdata dan proses peradilan pidana tetap dijalankan. Namun sebenarnya apabila kita mempermasalahkan mediasi penal dalam hal penentuan pengganti kerugian dari pelaku kepada korban hal ini dimungkinkan, yang dapat dijadikan dasar pertimbangan hakim dalam menjatuhkan pidana bersyarat. Ganti kerugian terhadap korban dalam pidana bersyarat merupakan salah satu syarat khusus yang telah dilakukan oleh terpidana, di samping ketentuan pidana yang akan dijatuhkan oleh hakim tidak lebih dari 1 (satu) tahun untuk pidana penjara.

Apabila dalam mediasi dicapai kesepakatan, maka mediator memberitahukan kepada penyidik bahwa telah dicapai kesepakatan melalui mediasi dengan pembayaran ganti kerugian dari pelaku kepada korban. Hasil kesepakatan mediasi penal merupakan putusan final, sehingga merupakan alasan penghapus penuntutan. Dengan adanya hasil kesepakatan maka penyidik menyatakan bahwa kasus tidak dilanjutkan kepada pelimpahan BAP kepada penuntut. Dalam pelaksanaan mediasi penal di tahap penuntutan ini dilakukan sekaligus negosiasi ganti kerugian antara pelaku dan korban. Mediasi penal pada tahap penuntutan ini merupakan kombinasi antara bentuk Victim-Offender Mediation dan Reparation Negotiation Programme. Bentuk reparation negotiation programme dititikberatkan pada pembayaran kompensasi dari pelaku kepada korban. Sedangkan bentuk victim offender mediation, dititikberatkan 
pada konsep rekonsiliasi dan pada kesepakatan pembayaran ganti kerugian kepada korban.

\section{Kesimpulan}

Hasil penelitian adalah sebagai berikut:

a. pelaksanaan mediasi penal yang dilaksanakan berdasarkan diskresi oleh Kepolisian Resor Kulonprogo, Sektor Galur melalui institusi perpolisian masyarakat yaitu dengan melibatkan banyak pihak selain pihak pelaku dan korban, juga melibatkan stakeholder seperti tokoh masyarakat dan tokoh agama yang tergabung di FKPM.

b. Faktor pendukung dan penghambat dari pelaksanaan mediasi pidana oleh Kepolisian Resor Kulonprogo, Sektor Galur yaitu anara lain: substansi undangundang Nomor 2 tahun 2002 tentang Kepolisian Negara Republik Indonesia yang memberikan kebebasan kepada pihak kepolisian pada saat pelaksanaan segala tugas, kewajiban dan wewenangnya dalam penegakan hukum; Kedua, petugas penyidik; Ketiga, Faktor masyarakat yaitu pengaruh situasi orang lain, kelompok orang atau masyarakat menurut anggapan atau penilaian petugas dalam penegakan hukum, khususnya dalam rangka pemberian atau penggunaan wewenang diskresi. Kedua, Faktor budaya yaitu keseluruhan nilainilai yang ada di masyarakat mempengaruhi tindakan-tindakan polisi, termasuk dalam hal pemberian diskresi.

c. Pola mediasi penal oleh Kepolisian Resor Kulonprogo, Sektor Galur yaitu keputusan untuk menghentikan kasus pidana setelah ditempuh jalan penyelesaian melalui musyawarah yang melibatkan terutama korban dan pelaku, serta tokoh agama, tokoh masyarakat dan unsur pemerintahan setempat. Melalui pertimbangan dan kesepakatan-kesepakatan yang diambil dalam forum musyawarah pihak kepolisian tidak melanjutkan proses perkara ke proses berikutnya. Hal tersebut diambil dengan pertimbangan bahwa keadilan telah dirasakan oleh kedua belah pihak dengan salah satu bersedia menanggung pengobatan yang lainnya dan bersedia untuk meminta maaf kepada korban.

\section{Daftar Pustaka}

Bambang Sunggono. (2003). Metodologi Penelitian Hukum, Raja Grafindo Persada, Jakarta.

Barda Arif Nawawi. (2008). Mediasi Penal: Penyelesaian Perkara Pidana di Luar Pengadilan, Program Magister Ilmu Hukum Pascasarjana UNDIP.

Barda Nawawi Arief. (2008). Mediasi Penal Penyelesaian Perkara Di luar Pengadilan. Semarang: Pustaka Magister. 
Bejo Suryo Hadi Purnomo. (2018) Kedudukan Mediasi Penal Dalam Sistem Peradilan Pidana di Indonesia. Jurnal Ilmiah Ilmu Sosial, Vol.4, No.2, Desember 2018, pp. 187-199.

Dwiasih Nadyanti, Putri Nabila K. A., Tiara Jayaputeri. Urgensi Penerapan Mediasi Penal Sebagai Alternatif Penyelesaian Perkara Pidana Ringan Di Luar Pengadilan. Adil: Jurnal Hukum Vol. 9 No.2, pp. 100-117.

Lilik Mulyadi, Mediasi Penal Dalam Sistem Peradilan Pidana Indonesia: Pengkajian Asas, Norma, Teori dan Praktek, Yustisia, Vol.2 No.1 Januari-April 201, pp. 1-14.

Lilik Prihatini. (2015). Perspektif Mediasi Penal Dan Penerapannya Dalam Perkara Pidana. Pakuan Law Review, Vol.1, No.1, Januari-Juni 2015, pp. 1-46.

Mudzakkir. (2007). “Alternative Dispute Resolution (ADR): Penyelesaian Perkara Pidana Dalam Sistem Peradilan Pidana Indonesia". Makalah Workshop, Jakarta, 18Januari2007.

Satjipto Rahardjo. (2002). Tentang Community Policing di Indonesia dalam Bunga Rampai Ilmu Kepolisian Indonesia, Editor Parsudi Suparlan. Jakarta: Yayasan Pengembangan Kajian Ilmu Kepolisian.

Satjipto Rahardji. (2002). Polisi Sipil: dalam Perubahan social di Indonesia, editor: Hasyim Asy'ari, Jakarta: Penerbit Buku Kompas.

Romli Atmasasmita. (2008). "Sinergi Kerja Polri Dan Kejaksaan Agung Dalam Sistem Peradilan Pidana di Indonesia," Makalah disampaikan pada Seminar Hubungan Polisi - Jaksa: Menuju Integrasi, di Auditorium Bumi Putera -Fakultas Ilmu Sosial dan Ilmu Politik Univ. Indonesia, Depok, 17 April 2008

Ronny Hanitijo Soemitro (1988). Metodologi Penelitian Hukum Dan Jurimetri. Ghalia. Jakarta.

Rudini Hasyim Rado, Barda Nawawi Arief, Eko Soponyono. (2016). Kebijakan Mediasi Penal Terhadap Penyelesaian Konflik Sara Di Kepulauan Kei Dalam Upaya Pembaharuan Hukum Pidana Nasional. Jurnal Law Reform, Vol.12, No.2, Tahun 2016, pp. 266-276.

Sahuri Lasmadi. (2011). Mediasi Penal, Sistem Peradilan Pidana Indonesia. Inovatif, Vol.4, No.5, Juli 2011, pp. 1-10.

Soekanto. (1986). Pengantar Peneltian Hukum, Yogyakarta: Universitas Indonesia (UI) Press.

Soerjono Soekanto dan Sri Mamudji. (2006). Penelitian Hukum Normatif, Raja Grafindo Persada, Jakarta.

Stephen R. Covey. (1989). The Seven Habits of Highly Effecive People, Powerful Lesson in Personal Change. USA, Free Press.

Taufiqurrohman Abildanwa. (2016). Mediasi Penal Sebagai Upaya Dalam Rangka Pembaharuan Hukum Pidana di Indonesia Berbasis Nilai-Nilai Keseimbangan. Jurnal Pembaharuan Hukum, Vol.3, No. 1 Januari - April 2016, pp. 138-148.

\section{Peraturan Perundang-undangan}

Undang-Undang Nomor 2 Tahun 2002 tentang Kepolisian Negara Republik Indonesia. 
Undang-Undang Nomor 30 tahun 1999 tentang Arbitrase dan Alternatif Penyelesaian Sengketa.

Peraturan Mahkamah Agung Republik Indonesia No. 2 Tahun 2012 tentang Penyesuaian Batasan Tindak Pidana Ringan dan Jumlah Denda dalam KUHP

Surat Telegram Kabareskrim Kepolisian Negara Republik Indonesia No.Pol.: STR/583/VIII/2012 yang di tujukan kepada para Kapolda, Dirreskrimum, Dirreskrimsus dan Dirresnarkoba di seluruh wilayah Indonesia. 